\title{
Taxonomic Note: V. B. D. Skerman (1921-1993), a Reforming Force in Bacterial Systematics and Nomenclature
}

\author{
L. I. SLY* \\ Centre for Bacterial Diversity and Identification, Department of Microbiology, \\ The University of Queensland, Brisbane, Queensland, Australia 4072
}

\begin{abstract}
Professor V. B. D. Skerman made major contributions to the reform of bacterial systematics which are now in place and appreciated. He was the catalyst and a driving force for a series of reforms which led to the clarification of bacterial nomenclature. He reorganized the International Committee on Systematic Bacteriology and the Judicial Commission by persuading the members to accept and develop the statutes that govern their operations and also persuaded them to adopt a new starting date for bacterial nomenclature. The resulting revision of the International Code of Nomenclature of Bacteria and the publication of the Approved Lists of Bacterial Names under his direction leave a legacy of procedures for the orderly progress of bacterial taxonomy and nomenclature.
\end{abstract}

Emeritus Professor Victor B. D. Skerman, who died on 5 November 1993 at age 72, will be remembered for his dedication to bacteriology and for his contributions to the reform and progress of bacterial systematics, for which he received international recognition. He was born in Toowoomba, Queensland, Australia, on 4 February 1921 and graduated with a Diploma of Agriculture from the Queensland Agricultural College at Lawes in 1938; this was followed by a Bachelor of Agricultural Science from the University of Queensland in 1941.

Professor Skerman began his working career as a bacteriologist at the Dairy Research Laboratories of the State Department of Agriculture and Stock in Brisbane in 1942. This appointment was terminated in favor of postgraduate study, which led to the award in 1943 of Honours in Agriculture with a major in microbiology. In 1944 he took a position as a Demonstrator in Bacteriology at the University of Melbourne and became a Senior Lecturer by 1948. In 1950 he moved to the University of Queensland, and after successive appointments as Chief Lecturer and Reader in Bacteriology, he was promoted to Professor of Microbiology and Head of Department in 1962, a position which he held until 1981.

A number of themes relating to his interest in the nomenclature and taxonomy of bacteria run through Professor Skerman's research. His skill at the laboratory bench and growing difficult bacteria led to his keys for the identification of bacteria $(12-14,16,17)$ and his book $A$ Guide to the Identification of the Genera of Bacteria $(14,16)$, which were widely used. In recent years the Approved Lists of Bacterial Names, which was prepared with other workers on behalf of the International Committee on Systematic Bacteriology (ICSB) (18), has had a major impact on bacteriology throughout the world; publication of this work marked the successful culmination of a long-held ambition to reform the nomenclature of bacteria.

The notion that bacterial classification and nomenclature were in need of radical change dawned quickly on the young V. B. D. Skerman following graduation. Faced with the challenge of identifying isolates, he soon realized that the process of identification, the practical outcome of classification, was a difficult and imprecise process, which was hampered by poorly characterized and described species, excessive levels of synonomy, and invalid nomenclature.

* Phone: 617365 2396. Fax: 617365 1566. Electronic mail address: sly@biosci.uq.oz.au.
Professor Skerman was a practical person and given to active intervention, so it is not surprising that he embarked on a mission to reform taxonomic procedures. Early on, he recognized that success in his mission would depend on changes to the rules that govern classification and nomenclature and that the ability to influence change would require close involvement with the organizations which draft, review, and administer the rules. This understanding influenced his philosophy, and he began a career during which he was heavily involved and committed to the international administration of and service to scientific organizations concerned with microbiology, particularly bacterial systematics, and culture collections (20). Professor Skerman was not dictatorial in achieving the reforms, but he spared no effort in trying to involve worldwide contributions through extensive and voluminous correspondence to arrive at a consensus or solution. He always endeavored to induce colleagues and committees to be definite, clear, and consistent in all their dealings and decisions. He also contributed in practical ways, such as by devising the identification keys that he provided for several editions of Bergey's Manual of Determinative Bacteriology $(13,17)$. During his career he was the Australian representative member on the ICSB (1950 to 1982), Chairman of the ICSB (1966 to 1978), a member of the Judicial Commission of the ICSB (1958 to 1982), Chairman of the Subcommittee on Numerical Taxonomy of the ICSB, a member of the Advisory Council of the International Association of Microbiological Societies (1962 to 1978), and Chairman of the International Association of Microbiological Societies Section on Culture Collections (1962 to 1970). He was the first chairman of the Queensland Branch of the Australian Society for Microbiology (1959 to 1961) and Federal President from 1965 to 1967.

Professor Skerman would be the first to recognize that the reforms achieved were the result of a team effort, but it is fair to say that the reforms might have stalled without his determination and will to see the difficult task through. Sneath (21), a close colleague in many of the reforms, paid tribute to Skerman's vision and persistence, which were exemplified by the fact that his solution to the problem of excessive synonomy advocated in 1949 (12) was not realized until 1981, when a new starting date for bacterial nomenclature was adopted (18). Other taxonomists and close collaborators with whom he worked are co-authors of international reports and publications in which the reforms were introduced (see, for example, references 4 and 18). However, many others made consider- 
able contributions as members of taxonomic committees or as individuals, and he always acknowledged the importance of these contributions. The path of reform was long and not without its critics and culminated in the publication of the Approved Lists of Bacterial Names in 1980 (18). A number of steps were required. These were: revision of the International Code of Nomenclature of Bacteria (1976 Revision) to allow the changes; a new starting date for bacterial nomenclature; compilation of the starting document of retained names now known as the Approved Lists of Bacterial Names; and establishment of official procedures for recording, publishing, and validating new names, including effective statutes of the ICSB and its Judicial Commission $(4,18,21)$. The intention and the result were the correction of a chaotic situation, and this solution ensured avoidance of a similar situation in the future.

Despite his extensive administrative and teaching commitments, Professor Skerman maintained an active research interest throughout his career and published more than 50 research publications and 9 books on bacterial systematics. His long-held interest in and research on the bacteria of natural freshwaters and soils were consolidated in the 1970s and 1980s with the publication of studies on the myxobacteria (8), the family Azotobacteracae (23), and the genera Herpetosiphon (9) and Saprospira (11). During these studies, which were performed with various students and colleagues, a number of new species and genera of bacteria were described, including Chitinophaga pinensis, a new genus of gliding bacteria (10); Agitococcus lubricus, a lipolytic twitching coccus isolated from freshwater (2); Conglomeromonas largomobilis, a sodium-sensitive mixed-flagellated organism isolated from freshwaters now included in the genus Azospirillum (19); and Gemmata obscuriglobus, a new species of budding bacteria (3). Professor Skerman's keen observation of natural processes and phenomena under the microscope and his patience with these observations were rewarded by the discovery of the predatory habits of Saprospira and Herpetosiphon species on other bacteria, which he described in detail $(9,11)$. He was always innovative in his research approach and developed and described a number of new techniques. The most important of these was the development of a micromanipulator (15), whose adaptability to fit almost any microscope and simplicity have resulted in worldwide use and application for the isolation of novel microorganisms.

Professor Skerman believed strongly that culture collections occupy a central position in systematics and nomenclature. His efforts in this area, which have been acknowledged elsewhere $(1,20)$, made significant contributions to the documentation of the World's culture collection resources and species inventories $(5-7,22)$.

Professor Skerman received a number of distinguished awards during his career, including the degree of Doctor of Science of the University of Queensland in 1961 for his research achievements, Fellow of the World Academy of Arts and Science in 1968, a Distinguished Service Medal from the International Union of Microbiological Societies in 1982, and Honorary Life Membership of the ICSB in the same year. In 1993 he received the Bergey Medal from the Bergey Trust in appreciation of his contribution to bacterial systematics and nomenclature. In 1986, he was elected an Honorary Member of the American Society for Microbiology; the citation indicated that the award was made in "highest recognition for outstanding contributions to the Science of Microbiology." $\mathrm{He}$ was also elected to Honorary Life Membership in the Australian Society for Microbiology in 1986.

Although Professor Skerman was best known for his pioneering work and leadership in bacterial nomenclature and taxonomy, I always felt that he viewed this work as the housekeeping that needed to be done so that the discovery and study of bacterial diversity and ecology could proceed in an orderly manner. Ironically, the organizational task was so great that it left him little time to pursue his other ambitions.

Professor Skerman's intention after his retirement in 1986 to write a third edition of his Guide to the Identification of the Genera of Bacteria and books on bacterial systematics for microbiologists in developing countries, for which he had such a close affection (1), was unfortunately not realized because of his declining health and untimely death in 1993. Through his achievements and reforms he made an outstanding contribution to bacterial systematics and nomenclature, the impact of which will be felt and appreciated for a long time to come.

The kind encouragement and assistance of Bob Murray during the preparation of this paper are acknowledged with thanks.

\section{REFERENCES}

1. Colwell, R. R., and E. DaSilva. 1994. Deceased members. ASM News 60:150

2. Franzmann, P. D., and V. B. D. Skerman. 1981. Agitococcus lubricus gen nov., sp. nov., a lipolytic twitching coccus from freshwater. Int. J. Syst. Bacteriol. 31:177-183.

3. Franzmann, P. D., and V. B. D. Skerman. 1984. Gemmata obscuriglobus, a new genus and species of the budding bacteria. Antonie Leeuwenhoek 50: 261-268.

4. Lapage, S. P., P. H. A. Sneath, E. F. Lessel, V. B. D. Skerman, H. P. R. Seeliger, and W. A. Clark (ed.) 1975. International code of nomenclature of bacteria. 1976 Revision. American Society for Microbiology, Washington, D.C.

5. Martin, S. M., and V. B. D. Skerman, 1970. World directory of collections of cultures of microorganisms. Wiley Interscience, New York.

6. McGowan, V., and V. B. D. Skerman. 1982. World directory of collections of cultures of microorganisms, 2nd ed. World Data Centre, University of Queensland, Brisbane, Queensland, Australia.

7. McGowan, V., and V. B. D. Skerman. 1986. World directory of collections of cultures of microorganisms, 3rd ed. World Data Centre, University of Queensland, Brisbane, Queensland, Australia.

8. McNeil, K. E., and V. B. D. Skerman. 1972. Examination of myxobacteria by scanning electron microscopy. Int. J. Syst. Bacteriol. 22:243-250.

9. Quinn, G. R., and V. B. D. Skerman. 1980. Retrofilation and tumulation by strains of Herpetosiphon spp. Curr. Microbiol. 3:345-348.

10. Sangkhobol, V., and V. B. D. Skerman. 1981. Chitinophaga, a new genus of chitinolytic myxobacteria. Int. J. Syst. Bacteriol. 31:285-293.

11. Sangkhobol, V., and V. B. D. Skerman. 1981. Saprospira species-natural predators. Curr. Microbiol. 5:167.

12. Skerman, V. B. D. 1949. A mechanical key for the generic identification of bacteria. Bacteriol. Rev. 13:175-188.

13. Skerman, V. B. D. 1957. A key for the determination of the generic position of organisms listed in the manual, p. 987-1032. In R. S. Breed, E. G. D. Murray, and N. R. Smith (ed.), Bergey's manual of determinative bacteriology, 7 th ed. Williams and Wilkins, Baltimore.

14. Skerman, V. B. D. 1959. A guide to the identification of the genera of bacteria. Williams and Wilkins, Baltimore.

15. Skerman, V. B. D. 1967 . A new type of micromanipulator and microforge. J. Gen. Microbiol. 54:287-297.

16. Skerman, V. B. D. 1967 . A guide to the identification of the genera of bacteria, 2nd ed. Williams and Wilkins, Baltimore.

17. Skerman, V. B. D. 1974. A key for the determination of the generic position of organisms listed in the manual, p. 1098-1146. In R. E. Buchanan and N. E Gibbons (ed.), Bergey's manual of determinative bacteriology, 8th ed. Williams and Wilkins, Baltimore.

18. Skerman, V. B. D., V. McGowan, and P. H. A. Sneath. (ed.). 1980. Approved lists of bacterial names. American Society for Microbiology, Washington, D.C.

19. Skerman, V. B. D., L. I. Sly, and M.-L. Williamson. 1983. Conglomeromonas largomobilis gen. nov., sp. nov., a sodium-sensitive mixed flagellated organism from fresh waters. Int. J. Syst. Bacteriol. 33:300-308.

20. Sly, L. I. 1994. Obituary, Victor Bruce Darlington Skerman. World Fed. Culture Collections Newsl. 22:3-4.

21. Sneath, P. H. A. 1986. Nomenclature of bacteria, p. 36-48. In W. D. L. Ride and T. Younes (ed.), Biological nomenclature today, a review of the present state and current issues of biological nomenclature of animals, plants, bacteria and viruses. IUBS Monograph Series. IRL Press, Oxford.

22. Sneath, P. H. A., and V. B. D. Skerman. 1966. A new list of type and reference strains of bacteria. Int. J. Syst. Bacteriol. 16:1-133.

23. Thompson, J. P., and V. B. D. Skerman. 1979. Azotobacteraceae: taxonomy and ecology of aerobic nigrogen fixing bacteria. Academic Press, London. 